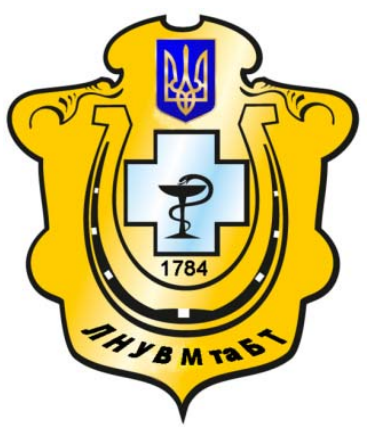

Науковий вісник Львівського національного університету ветеринарної медицини та біотехнологій імені С.3. Гжицького

Scientific Messenger of Lviv National University of Veterinary Medicine and Biotechnologies named after S.Z. Gzhytskyj

doi:10.15421/nvlvet6809

ISSN 2413-5550 print

ISSN 2518-1327 online

$\underline{\text { http://nvlvet.com.ua/ }}$

УДК 637.5

\title{
Дослідження ферментного препарату трансглютамінази на модельних зразках реструктурованих шинок 3 яловичини
}

\author{
I.I. Кишенько ${ }^{1}$, Ю.П. Крижова ${ }^{2}$, М.І. Філоненко ${ }^{1}$ \\ yuliya.kryzhova@mail.ru \\ ${ }^{1}$ Національний університет харчових технологій, \\ вул. Володимирська, 68, м. Київ, 01601, Украӥна; \\ ${ }^{2}$ Начіональний університет біоресурсів і природокористування Украӥни, \\ вул. Героїв Оборони, 11, м. Київ, 03041, Украӥна
}

\begin{abstract}
Науково-практичне рішення проблеми перетворення реструктурованої м'ясної системи до теплової обробки з отриманням структурних якостей иільном'язової тканини є актуальною задачею розвитку сучасної технології як науки про м'ясо. При вивченні даної проблеми найкращий результат був досягнутий при використанні ферментних препаратів, $i$ в першу чергу ферменту трансглютамінази. Мікробіальна трансглютаміназа в кількості 0,075\% забезпечує реструктурованим продуктам монолітність і покращує здатність їх до нарізання. Проведені раніше наукові дослідження підтвердили той факт, щз трансалютаміназа також здатна підвищувати функиіональність сироваткових білків у продуктах із подрібненого м'яса. Для досліджень були виготовлені дослідні зразки реструктурованих шинок з яловичини 1 сорту із заміною м'ясної сировини 3,0; 4,5; 6,0; 7,5\% гідратованим білковим препаратом «Drip freе саs». Раціональною кількістю, щьо сприяє покращенню структурно-механічних характеристик реструктурованих иинок, є внесення 0,075\% трансглютамінази та 0,15\% харчових фосфатів при заміні 6\% м'ясної сировини сироватковим білковим препаратом "Drip freе саs». Проведені дослідження підтвердили той факт, що розчини 0,065\%, 0,075\% та 0,085\% трансглютамінази проявляють буферні властивості та стабілізують значення рН модельних м'ясних систем в процесі масажування, підвищують вологозв'язуючу здатність, а внесення трансалютамінази в кількості 0,075\% сприяє збільшенню напруги різання дослідних зразків шинок на 7,7\% у порівнянні із зразками, які містять 0,065\% фермента.

Ключові слова: трансглютаміназа, структура, білковий препарат, яловичина, иинка реструктурована.
\end{abstract}

\section{Исследованиеферментного препарата трансглютаминазы на модельных образцах реструктурированных ветчин из говядины}

\author{
И.И. Кишенько ${ }^{1}$ Ю.П. Крыжова ${ }^{2}$ М.И. Филоненко ${ }^{1}$ \\ yuliya.kryzhova@mail.ru \\ ${ }^{1}$ Национальный университет пищевых технологий, \\ ул. Владимирская, 68, г. Киев, 01601, Украина; \\ ${ }^{2}$ Национальный университет биоресурсов и природопользования Украины, \\ ул. Героев Обороны, 11, Киев, 03041, Украина
}

\begin{abstract}
Научно-практическое решение проблемы преобразования реструктурированной мясной системы до тепловой обработки с получением структурных качеств цельномышечной ткани является актуальной задачей развития современной технологии как науки и мясе. При изучении этой проблемы наилучший результат был достигнут при использовании ферментных препаратов, и в первую очередь фермента трансглютаминазы. Микробиальная трансалютаминаза в количестве 0,075\% обеспечивает реструктурированным продуктам монолитность и улучшает способность их к нарезанию. Проведенные ранее исследования подтвердили тот факт, что трансглютаминаза также способна повышать функииональность сывороточных белков
\end{abstract}

\section{Citation:}

Kishenko, I.I., Kryzhova, Y.P., Filonenko, M.I. (2016). Research of fermented compound transglutaminase on the model samples of restrustured beef ham. Scientific Messenger LNUVMBT named after S.Z. Gzhytskyj, 18, 2(68), 46-50. 
в продуктах из измельченного мяса. Для исследований были выработаны опытные образцьы реструктурированных ветчин из говядины 1 сорта с заменой мясного сырья 3,0; 4,5; 6,0; 7,5\% гидратированным белковым препаратом «Drip freе сал». Рациональным количеством, способствуюшим улучшению структурно-механических характеристик реструктурированных ветчин, является внесение 0,075\% трансллютаминазы и 0,15\% пищевых фосфатов при замене 6 \% мясного сырья гидратированнылм сывороточным белковым препаратом «Drip freе саs». Проведеннье исследования подтвердили тот факт, что растворы 0,065\%, 0,075\% и 0,085\% трансглютаминазы проявляют буферные свойства и стабилизируют значения рН модельных мясных систем в прочессе массирования, увеличивают влагосвязываюшую способность, а внесение трансглютаминазы в количестве 0,075\% способствует увеличению напряжения среза опытных образцов ветчин на 7,7\% по сравнению с образцами, содержашими 0,065\% фермента.

Ключевые слова: трансглютаминаза, структура, белковый препарат, говядина, ветчина реструктурированная.

\title{
Research of fermented compound transglutaminase on the model samples of restrustured beef ham
}

\author{
I.I. Kishenko ${ }^{1}$, Y.P. Kryzhova ${ }^{2}$, M.I. Filonenko ${ }^{1}$ \\ yuliya.kryzhova@mail.ru \\ ${ }^{I}$ National University of Food Technologies, \\ Volodymyrska Str., 68, Kyiv, 01601, Ukraine; \\ ${ }^{2}$ National University of life and environmental sciences of Ukraine, \\ Heroyiv Oborony Str., 11, Kyiv, 03041, Ukraine
}

Scientific-practical solution of the transformation problem of the restructured meat system up to heat treating, and obtaining structural qualities of the whole muscle tissue is an actual assignment of the modern technologies development, as well as a science about meat. While studying this problem, the best result was achieved with the use of fermented compounds and, primarily, transglutaminase enzyme.Microbial transglutaminase in the quantity of $0.075 \%$ provides consolidation of restructured products and improves their ability of cutting. Earlier conducted scientific studies proved the fact that transglutaminase can increase the functionality of whey proteins in products with milled meat. For this research trial examples of restructured hams from the first sort beef with the substitution of processing meat 3.0; 4.5; 6.0; 7.5\% by hydrated protein compound «Drip free cas» were produced.

The rational quantity that enables improvement of structural-mechanical characteristics of restructured hams is insertion of $0.075 \%$ of transglutaminase and $0.15 \%$ of food phosphates with substitution of $6 \%$ of processing meat for hydrated wheyey protein compound «Drip free cas». Fulfilled researches proved the fact that solutions $0.065 \%, 0.075 \%$ and $0.085 \%$ of transglutaminase display buffer properties and stabilize $\mathrm{pH}$ value of model meat systems in the process of massaging, increase water-binding power, and adding of transglutaminase in the quantity of $0.075 \%$ helps to increase shear stress of hams test models for $7.7 \%$ in comparison with samples that contained $0.065 \%$ of the ferment.

Key words: transglutaminase, structure, protein compound, beef, restructured ham.

\section{Вступ}

Багатокомпонентні м'ясні системи відрізняється великою варіабельністю сировинного складу і особливістю функціонально-технологічних властивостей. Особливий інтерес представляють ферменти, які сприяють формуванню структури м'ясних продуктів, до яких відноситься трансглютаміназа (ТГЛ). Використання ферментного препарату дозволяє вирішити ряд технологічних завдань при виробництві м'ясопродуктів цілеспрямованим регулюванням водо- і жироутримуючій здатності, а також структурно-механічних властивостей м'ясних систем (Semenova et al., 2011; Ishevskiy and Karlova, 2012). Технологічний ефект дії ТГЛ на білкові молекули здійснюється за рахунок структуризації білкових молекул, зруйнованих механічною і біохімічною дією. В результаті цієї дії відбувається утворення ковалентних зв'язків між аміногрупами як білкових молекул одного виду, так і між білковими молекулами, що відрізняються за типом, наприклад казеїном, міозином, глобуліном або актином тваринних білків і глютеном пшеничної клейковини, що сприяє «зшиванню» білкових складових у багатокомпонентних м'ясних системах. В результаті ферментативної дії утворюються високомолекулярні з'єднання, які містять глютаміллізинові внутрішні і міжмолекулярні зв'язки, що впли- вають на структуру продукту і функціональні властивості білків. Ковалентні зв'язки, утворені трансглютаміназою між вільними аміногрупами і гаммакарбоксильними групами глутаміну стійкі до протеолиiу. Зв'язки утворюються як усередині молекули протеїну, так і між окремими його молекулами. Це дозволяє утримувати більшу кількість води в новій утвореній білковій структурі, формувати однорідну щільну структуру емульгованих м'ясних продуктів, знижувати концентрацію кухонної солі і фосфатвмісних харчових добавок в рецептурі м'ясопродуктів. Крім того, фермент сприяє дезамінуванню природних амінокислот $\mathrm{i}$ біосинтезу нових амінокислот, що призводить до поліпшення функціонально-технологічних властивостей м'ясних систем (Kuraishi et al., 1997; Ramirez-Suarez and Xiong, 2003; Kurshchaeva et al., 2014). Створена таким чином білкова структура стабільна в широкому діапазоні $\mathrm{pH}$ і температур, а також стійка до механічних дій (Motoki and Seguro, 1998; Ramirez-Suarez and Xiong, 2002).

У традиційній технології виробництва реструктурованих продуктів для отримання однорідного продукту, підвищення виходу готових виробів застосовують синтетичні технологічні добавки.

3 метою отримання оптимального технологічного ефекту були проведені дослідження, спрямовані на 
визначення раціональної кількості трансглютамінази у складі реструктурованих м'ясних систем. В ході експериментальних досліджень визначали дію ферменту трансглютамінази на реструктуровані модельні м'ясні системи для шинкових виробів з яловичини 1 сорту.

Результати досліджень обробляли методом математичної статистики. Довірча вірогідність була задана на рівні $\mathrm{P} \geq 0,95$ при 3 - 5-ти кратній повторності вимірів.

Нами була використана мікробіальна форма кальційнезалежного ферменту, що продукується бактеріями Streptoverticilti-um mobamense, активністю 50 од./г порошку. Така трансглютаміназа продукується генетично немодифікованим мікроорганізмом ((Semenova et al., 2011; Ishevskiy and Karlova, 2012; Kurshchaeva et al., 2014). Температурний діапазон активності трансглютамінази складає від 0 до $65^{\circ} \mathrm{C}$, причому оптимальна хімічна активність досягається приблизно при 55 ${ }^{\circ} \mathrm{C}$. Крім того, ii стабільність не залежить від інших компонентів системи, в якій вона знаходиться, а утворена ферментом білкова матриця подібна до природної структури білкової тканини.

Інактивація трансглютаминазы спостерігається в результаті температурної дії, кислотності середовища i тривалого контакту 3 киснем. Повне руйнування ферменту відбувається при температурі $72-75{ }^{\circ} \mathrm{C}$ впродовж 5 - 10 хвилин. Це забезпечує безпеку його використання у виробництві м'ясопродуктів. Результатом теплової інактивації ферменту $\epsilon$ залишкові пептидні зв'язки, отримані в процесі теплової деструкції білкової молекули ферменту.

Цей фермент активний в досить широкому інтервалі $\mathrm{pH}(4-9)$, причому, оптимальне значення $\mathrm{pH}$ складає $6-7$. У активному центрі ферменту присутній цистеїновий залишок, так що за певних умов фермент може окиснюватися.

Метою роботи є дослідження ферментного препарату трансглютамінази на модельних зразках реструктурованих шинок з яловичини.

\section{Матеріал і методи досліджень}

В роботі використано аналітичні та експериментальні методи досліджень: фізико-хімічні (для визначення якісного і кількісного складу, функціональнотехнологічних характеристик), інструментальні (для структурно-механічних характеристик), амінокислотного та жирнокислотного складу), математичні та математично-статистичні (для математичного моделювання, оптимізації статистичного оброблення експериментальних даних).

\section{Результати та їх обговорення}

При виготовленні модельних зразків з яловичини 1 сорту їі заздалегідь подрібнювали на вовчку з діаметром отворів решітки 25 мм і масажували в масажорі впродовж 6 годин в режимі: 15 хв масажування, 15 хв спокою, у присутності $30 \%$ розсолу. 3 літературних джерел відомо, що позитивний вплив на ступінь зв'язування мікробіальної трансглютамінази роблять сіль i фосфати, що обумовлено їх здатністю солюбілізувати поверхневі м'язові білки. До складу розсолу для масажування вводили: 2,5\% кухонної солі, 0,3\% суміші триполіфосфатів, 0,3\% цукру і 0, 0075\% нітриту натрію.

Після закінчення масажування м'ясну масу вивантажували і витримували в посолі при температурі $(2 \pm$ 2) ${ }^{\circ} \mathrm{C}$ впродовж 24 годин, потім повторно піддавали масажуванню в мішалці з додаванням 6\% до маси сировини гідратованого білкового препарату «Drip free cas», і перемішували упродовж 10 хв.

Після цього посолену сировину ділили на чотири частини, в три 3 яких вводили $0,065 \%, 0,075 \%$ i 0,085\% трансглютамінази, заздалегідь розведеної в невеликій кількості холодної води температурою $4{ }^{\circ} \mathrm{C}$, і також масажували 15 хв (одна частина м'ясної сировини залишилася контрольною). Вимір показника $\mathrm{pH}$ м'ясної системи проводили через 3, 6, 9 і 12 годин масажування (рис. 1). Після закінчення масажування формували м'ясну масу в оболонку, щоб уникнути хаотичного ï склеювання. Сформовані батони витримували у холодному приміщенні упродовж $8-10$ годин при температурі $6{ }^{\circ} \mathrm{C}$ до теплової обробки, після чого піддавали тепловій обробці до досягнення температури в центрі зразка $72{ }^{\circ} \mathrm{C}$, охолодження проводили до $8^{\circ} \mathrm{C}$. Зберігали готову продукцію упродовж 12 годин при температурі $6 \pm 2{ }^{\circ} \mathrm{C}$.

Стабілізація значень $\mathrm{pH}$ в процесі технологічної обробки м'ясної сировини трасглютаміназою $є$ одним 3 чинників м'ясопродуктів, що дозволяють формувати стандартні споживчі властивості. Проведені дослідження підтверджують той факт, що розчини $0,065 \%$, 0,075\% і 0,085\% трансглютамінази проявляють буферні властивості і стабілізують значення $\mathrm{pH}$ модельних м'ясних систем в процесі масажування. Як видно 3 графіку (рис.1), в процесі ферментації реструктурованих м'ясних систем, реакція середовища $\mathrm{pH}$ поступово збільшується і досягає максимуму при 6 годинах обробки, зміщуючись від 6,3 до 7,0.

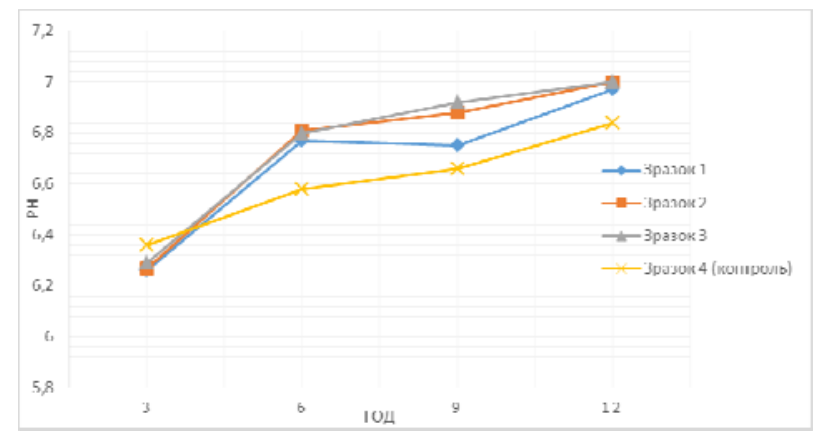

\section{Рис. 1. Динаміка зміни показника рН модельних ретруктурованих м'ясних систем в процесі маса- жування}

Зміну показника $\mathrm{pH}$ в динаміці можна обгрунтувати накопиченням продуктів гідролізу тваринних білків, причому, ефективніше процес протеолізу відбувався в м'ясних модельних системах зі збільшенням кількості ферментного препарату.

Зміщення величини $\mathrm{pH}$ від ізоелектричної точки сприяє підвищенню іонної сили розчинів білків і забез- 
печує інтенсивне набрякання білкових міцел, що призводить до збільшення рівня водозв'язуючої і водоутримуючої здатності реструктурованих м'ясних систем (рис. 2 і 3), а поперекові зв'язки, що утворюються між білками за допомогою трансглютамінази створюють сітчасту матрицю, що дозволяє «зшивати» шматочки сировини, ефективно утримувати додану вологу i м’ясний сік в м'ясній системі.

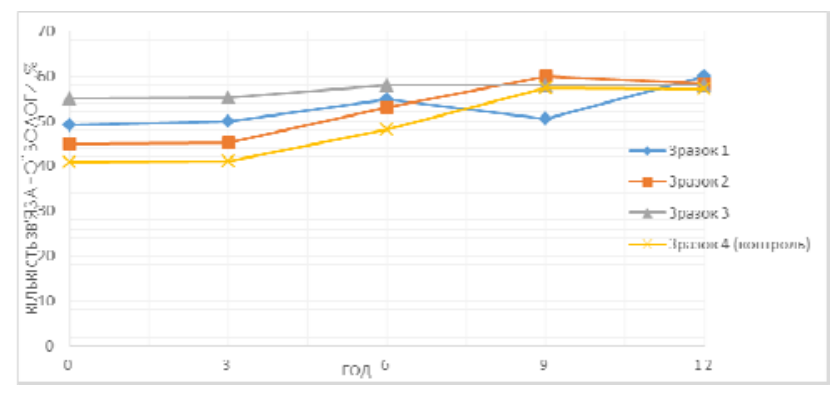

Рис.2. Динаміка зміни кількості зв'язаної вологи в модельних реструктурованих м'ясних системах в процесі масажування, \% до маси м'яса

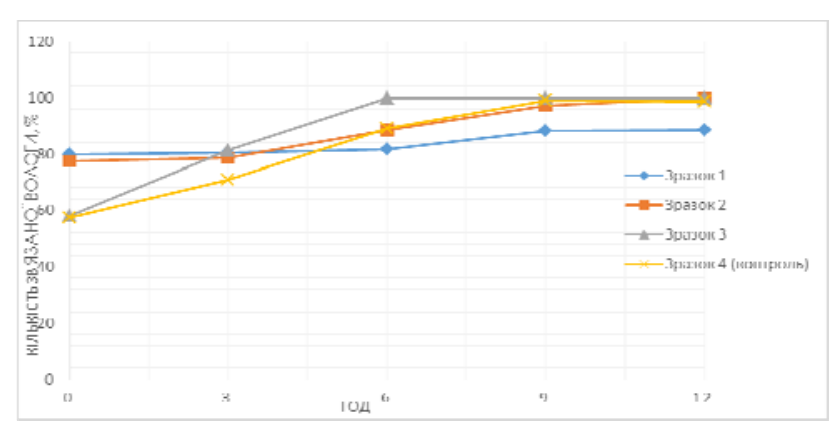

Рис.3. Динаміка зміни кількості зв'язаної вологи в модельних реструктурованих м'ясних системах в процесі масажування, \% до загальної вологи

При застосуванні ферменту трансглютамінази в дослідних зразках модельних реструктурованих м'ясних систем спостерігається зростання водозв'язуючої здатності упродовж усього процесу масажування системи. Так, в зразках № 3, що містять 0,085\% від маси сировини трансглютамінази, рівень зв'язаної вологи у відсотках до загальної вологи досягає значення 98,8\% уже через 4 годин масажування, в зразках № 1 і 2, що містять нижчу концентрацію того ж ферменту $(0,065$ і 0,075) - через 5 і 6 годин відповідно. Збільшення вологозв'язуючої здатності, ймовірно, пов'язане 3 накопиченням в м'ясній системі водо- i солерозчинних білків, що мають високу здатність до набрякання і утримання вологи. Разом 3 тим, підвищення вологозв'язуючої здатності реструктурованих м'ясних систем сприяє зменшенню втрати вологи i поживних компонентів при термообробці і підвищенню виходу готового продукту.

Структурно-механічні властивості модельних реструктурованих м'ясних систем визначають їх поведінку при технологічній переробці. Це дає можливість вста- новлювати раціональні технологічні умови процесу i забезпечувати бажану структуру і щільність пружноеластичнх продуктів, до яких відносять шинкові вироби. Результати визначення структурно-механічних властивостей реструктурованих м'ясних систем після 6 годин масажування свідчать про те, що внесення трансглютамінази у кількості 0,075\% сприяє збільшенню напруги різання дослідних зразків шинок, в порівнянні із зразками шинок, що містять 0,065\% ферменту. При збільшенні кількості трансглютамінази, що вноситься в розсіл, до 0,085\% значного зростання напруги різання не відбувалося - збільшення значення цієї характеристики склало $0,3-0,9 \%$. Тому для подальших досліджень з економічної доцільності було вибрано раціональну кількість - 0,075\% до маси м'ясної системи.

Результати досліджень фізико-хімічних і структурно-механічних показників модельних зразків шинкових виробів в оболонці свідчать про те, що введення в модельні м'ясні системи 3 яловичини 1 сорту трансглютамінази позитивно впливає на міцність їх структури в цілому, при цьому найбільш монолітними $\epsilon$ структури з 6\% заміни м'ясної сировини гідратованим сироватковим білковим препаратом. Використання ж білкового препарату «Drip free cas» і трансглютамінази дозволяє вирішити існуючі проблеми без значних змін інших показників якості і харчової цінності.

Рекомендована кількість ферменту залежить від джерела і вмісту білку, від доступності необхідних амінокислот для утворення поперекових «зшивань», від часу реакції і іï температури, від використовуваної технології і присутності в рецептурі інших компонентів, при цьому швидкість реакції трансглютамінази 3 м'язовими білками різна (Kuraishi et al., 1997; Motoki and Seguro, 1998; Ramirez-Suarez and Xiong, 2002).

3 літературних джерел відомо, що позитивний вплив на ступінь зв'язування мікробіальної трансглютамінази роблять сіль і фосфати, що обумовлено їх здатністю солюбілізувати поверхневі м'язові білки i, що, можливо, змінює технологічний ефект від внесення трансглютамінази. Тому для оцінки впливу спільної дії трансглютамінази і харчових фосфатів були досліджені зразки шинок з дозою внесення трансглютамінази 0,075\% і харчових фосфатів - 0,15, 0,3 i $0,4 \%$ (табл. 1 ).

Результати досліджень фізико-хімічних і структурно-механічних показників модельних зразків шинкових виробів в оболонці показують, що фосфати i трансглютаміназа незалежно один від одного впливають на модельні м'ясні системи з яловичини 1 сорту. Збільшення кількості фосфатів до 0,3\% збільшує значення вологоутримуючої здатності, при цьому утримана фосфатами волога робить незначний вплив на величину напруги різання. При подальшому збільшенні концентрації фосфатів відбувається зниження технологічного ефекту від їх дії на м'ясну систему, про що свідчить підвищення структурно-механічних характеристик, а не за рахунок дії трансглютамінази. 
Фізико-хімічні, структурно-механічні характеристики і вихід реструктурованої шинки 3 яловичини 1 с в оболонці

\begin{tabular}{|l|c|c|c|c|}
\hline \multirow{2}{*}{ Показники } & \multicolumn{4}{|c|}{ Кількість внесених фосфатів, \% } \\
\cline { 2 - 5 } & 0 & 0,15 & 0,3 & 0,4 \\
\hline Вміст вологи, \% & $67,83 \pm 0,34$ & $73,45 \pm 0,28$ & $74,26 \pm 0,21$ & $73,61 \pm 0,22$ \\
Вологоутримуюча & & & & \\
здатність, \% & $62,35 \pm 0,38$ & $64,72 \pm 0,21$ & $66,14 \pm 0,55$ & $63,30 \pm 0,58$ \\
Напруга різання, кПа & $189,86 \pm 1,42$ & $204,49 \pm 1,2$ & $191,85 \pm 1,38$ & $198,83 \pm 1,33$ \\
Вихід, \% & $105,22 \pm 1,3$ & $110,19 \pm 1,18$ & $109,14 \pm 1,11$ & $109,65 \pm 1,24$ \\
\hline
\end{tabular}

Враховуючи медико-біологічну необхідність у зниженні рівня вмісту харчових фосфатів у м'ясних продуктах і технологічну практику їх застосування, а також грунтуючись на результати проведених досліджень, можна зробити висновок про доцільність зниження рівня харчових фосфатів до 0,15\% при спільному використанні 0,075\% трансглютамінази.

Загальна органолептична оцінка досліджуваних зразків модельних шинок в оболонці була високою. Найбільш високими були показники модельних зразків шинок, які характеризували смак, колір і консистенцію досліджуваних зразків, що містять 0,075\% трансглютамінази, 0,15\% харчових фосфатів $36 \%$ заміною м'ясної сировини гідратованим сироватковим білковим препаратом «Drip free cas».

\section{Висновки}

1. Використання мікробіальної трансглютамінази у виробництві м'ясних реструктурованих продуктів 3 яловичини дозволяє переробляти недостатньо використовувану в м'ясопереробному виробництві високоцінну сировину.

2. Раціональною кількістю, яка сприяє поліпшенню структурно-механічних характеристик реструктурованих шинок, є внесення 0,075\% трансглютамінази i $0,15 \%$ харчових фосфатів при заміні 6\% м'ясної сировини гідратованим сироватковим білковим препаратом.

3. Внесення трансглютамінази в кількості 0,075\% у поєднанні та $0,15 \%$ харчових фосфатів забезпечує реструктурованим продуктам монолітність, еластичність, термостабільність, покращує їх органолептичні характеристики, здатність до нарізування, підвищує вологоутримуючу здатність.

Перспективи подальших досліджень. Проведені дослідження застосування ферментного препарату трансглютамінази у поєднанні з фосфатами та сироватковим білковим препаратом дає можливість викори- стовувати високоцінну сировину у м'ясопереробному виробницві, яка на сьогоднішній день переробляється у незначній кількості, з високими органолептичними характеристиками готового продукту.

\section{Бібліографічні посилання}

Ishevskiy, A.L., Karlova, V.A. (2012). O vozmozhnosti primeneniya enzimov dlya polusheniya naturalnich poluphabrikatov iz myasnoy obrezi. Vestnik mezhdunarodnoy akademii choloda. 2, 26 - 28 (in Russian).

Semenova, A.A., Tunieva, E.K., Gorbatov, S.A. (2011). Perspektivi ispolzovaniya transglyutaminazi dlya proizvodstv myasnich productov. Vse o myase. 2, 14-15 (in Russian).

Kurshchaeva, E.E., Lyutikova, A.O., Melnikova, E.S., Maksimov, I.V. (2014). Ispolzovaniye metodov biotechnologii dlya sozdaniya emulgirovannych myasnych produktov novogo pokoleniya. Aktualnuye napravleniya naushchnych issledovanii XXI veka: teoriya i praktika. 2. 4-3(9-3), 453-457 (in Russian).

Kuraishi, C., Sakamoto, J., Yamazaki, K., Susa, Y, Kuhara, C., Soeda, T. (1997). Production of restructured meat using microbial transglutaminase without salt or cooking. J. of Food Science. 62, 488-490.

Ramirez-Suarez, J.C., Xiong, Y.L. (2003). Rheological properties of mixed muscle/nonmuscle protein emulsions treated with transglutaminase at two ionic strengths. J. of Food Science and Technology. 38, 777-785.

Motoki, M., Seguro, K. (1998). Transglutaminase and its use for food processing. Trends in Food Science and Technology. 9, 204-210.

Ramirez-Suarez, J.C., Xiong, Y.L. (2002). Transglutaminase cross-linking of whey/myofibrillar proteins and the effect on protein gelation. Journal of Food Science. 67, 2885-2891.

Стаття надійшла до редакиії 5.09.2016 